\title{
ANALISIS PENGARUH KEBIJAKAN HUTANG DAN PROFITABILITAS TERHADAP HARGA SAHAM DENGAN KEBIJAKAN DIVIDEN DAN NILAI PERUSAHAAN SEBAGAI VARIABEL MEDIASI
}

\author{
Penulis : Muksan Junaidi ${ }^{*}$, Heru Sulistyo dan Sri Harjanto \\ STIE Dharmaputra Semarang \\ Jl. Pamularsih Raya No 16, Semarang, Indonesia \\ muchsan.djunaedi@gmail.com \\ sulistiyo.heru@yahoo.com \\ sriharjanto77@gmail.com
}

\begin{abstract}
ABSTRAK
Penelitian ini bertujuan untuk menganalisis pengaruh kebijakan hutang dan profitabilitas terhadap harga saham dengan kebijakan dividen dan nilai perusahaan sebagai variabel mediasi. Penelitian ini menggunakan jenis data sekunder bersifat kuantitatif yang diperoleh dari www.idx.co.id. Populasi datanya adalah seluruh perusahaan LQ45 non lembaga keuangan terdaftar di Bursa Efek Indonesia tahun 2011-2015. Metode pengambilan sampel dengan sensus atau sampel jenuh. Teknik analisis data yaitu analisis regresi linear berganda, jumlah sampel sebanyak 150, diuji dengan aplikasi SPSS dan Sobel Test.

Hasil analisis menunjukkan bahwa, DER berpengaruh negatif dan signifikan terhadap DPR. ROE berpengaruh positif dan signifikan terhadap DPR. DER berpengaruh negatif dan tidak signifikan terhadap PBV. ROE berpengaruh positif dan signifikan terhadap PBV.ROE berpengaruh positif dan tidak signifikan terhadap CP. DER berpengaruh negatif dan tidak signifikan terhadap CP. DPR berpengaruh positif dan signifikan terhadap CP. PBV berpengaruh positif dan signifikan terhadap CP. DER berpengaruh negatif dan signifikan terhadap CP dengan DPR sebagai variabel mediasi. ROE berpengaruh positif dan signifikan terhadap CP dengan DPR sebagai variabel mediasi. DER berpengaruh negatif dan tidak signifikan terhadap CP dengan PBV sebagai variabel mediasi. Dan ROE berpengaruh positif dan signifikan terhadap CP dengan PBV sebagai variabel mediasi.
\end{abstract}

Kata Kunci: Return On Equity (ROE), Debt Equity Ratio (DER), Price Book Value (PBV), Dividend Payout Ratio (DPR), Closing Price (CP), dan Mediasi.

\section{Latar belakang}

Perlambatan Ekonomi Indonesia tahun 2014 hingga akhir 2015 berdampak di pasar modal (Kompas.com, 30/05/2016). Perusahaan di BEI akhir 2015, mengalami penurunan volume perdagangan pada periode itu adalah Emiten LQ-45. Penyebabnya selain faktor ekonomi makro yaitu internal perusahaan pada aspek kebijakan pendanaan, profitabilitas yang mempengaruhi harga saham, serta faktor lain; kebijakan dividen dan rasio pasar.

Data pada (website IDX, 2015) indeks LQ45 menunjukan rata-rata harga saham penutupan di akhir 2015 cenderung berfluktuasi dari $12,44 \%$ menjadi $-1,86 \%$. Kebijakan hutang (DER) turun di 2015 dari 1.26x menjadi 1,04 x. Profitabilitas (ROE) turun di 2015 dari $21,66 \%$ menjadi $16,11 \%$. Penelitian pengaruh kebijakan hutang (DER) terhadap harga saham (CP) dilakukan oleh Raghilia Amanah (2014) dan Fillya Arum (2012) menunjukan pengaruh positif signifikan. Namun penelitian Abied Luthfi Safitri (2013) dan Wendy Cahyono (2013) menunjukan pengaruh positif tidak signifikan. Penelitian Mursidah (2011) menunjukkan pengaruh negatif dan tidak signifikan. Penelitian Desy Arista (2012), dan Christine Dwi (2012) menunjukan hasil berbeda yaitu berpengaruh negatif dan signifikan. Penelitian Pengaruh profitabilitas (ROE) terhadap harga saham (CP) dilakukan oleh Raghilla Amanah (2014) dan Mursidah (2011) menunjukan pengaruh negatif dan tidak signifikan. Penelitian Wendy Cahyono 
(2013) dan Daniel (2015) menunjukan hasil berbeda berpengaruh positif dan tidak signifikan. Penelitian Christine Dwi (2012) dan Rescyana Putri (2012) menunjukan pengaruh positif dan signifikan

Faktor lain sebagai solusi penelitian memakai kebijakan dividen (DPR) dan nilai perusahaan (PBV) sebagai mediasi yang menghubungkan kebijakan hutang (DER) dan profitabilitas (ROE) terhadap harga saham (CP).

Kebijakan dividen yang di proksikan Dividen Payout Ratio (DPR). Optimal dividend policy adalah kebijakan dividen yang menciptakan keseimbangan di antara dividen saat ini dan pertumbuhan di masa mendatang sehingga memaksimumkan harga saham perusahaan (Brigham dan Weston, 2005:199).

Menurut keown (1999) nilai perusahaan merupakan nilai pasar atas surat berharga hutang dan ekuitas pemegang saham yang beredar. Nilai perusahaan merupakan persepsi investor terhadap tingkat keberhasilan perusahaan sering dikaitkan dengan harga saham. Nilai perusahaan menggunakan Price Book Value (PBV)

Masalah dalam penelitian ini adalah Pengaruh Kebijakan Hutang dan Profitabilitas Terhadap Harga Saham yang di Mediasi oleh Kebijakan Dividen dan Nilai Perusahaan pada Emiten LQ45 Non Lembaga Keuangan di Bursa Efek Indonesia (BEI) Tahun 2011-2015.

\section{Teori Sinyal}

Menurut Brigham dan Houston (2011), sinyal (signal) adalah suatu tindakan oleh manajemen perusahaan dalam memberikan petunjuk bagi investor bagaimana manajemen menilai prospek perusahaan tersebut. Manajer lebih banyak memiliki informasi tentang perusahaan dibandingkan dengan investor (asymmetric information). Supaya terjadi (symmetric information), maka manajer memberikan sinyal kepada pihak luar berupa informasi keuangan terpercaya dan akan mengurangi ketidakpastian mengenai prospek perusahaan yang akan datang (Abdul Halim, 2005:23).

\section{Teori Keagenan}

(Michael C.J. dan William H.Meckling tahun , 1976) memaparkan pemisahan pengendalian perusahaan yaitu hubungan antara agen dan prinsipal. agen adalah pihak yang mengelola perusahaan, dan prinsipal adalah pemilik perusahaan. Sering terjadi konflik antara kedua pihak disebut agency conflict. Perusahaan yang profit cenderung memicu perilaku oportunitas manajer atau agen untuk disalah gunakan bagi kepentingan pribadi, maka dividen sebagai mekanisme control untuk mengatasi oportunitas. Teori keagenan menganggap bahwa dividen dan intensif bonus saham (stock bonus) kepada manajer, sebagai solusi perselisihan atau lebih lanjut antara pemegang saham luar dan pemegang saham pengendali, (Zumrotun Nafi'ah, 2013).

\section{Profitabilitas}

(Niswonger,Warren,Reeve dan Fess, 2004), mendefinisikan kemampuan perusahaan untuk memperoleh laba berhubungan dengan penjualan, total aktiva maupun modal sendiri. Profitabilitas dapat memberikan signal akan naiknya nilai perusahaan. Perusahaan yang memiliki tingkat profitabilitas yang tinggi akan diminati sahamnya oleh investor. Sehingga, besar kecilnya profitabilitas yang dihasilkan oleh perusahaan dapat berpengaruh pada harga saham (Candra Pami H, 2014).

\section{Kebijakan Hutang}

(Weston dan Brigham, 2011) mendefinisikan financial leverage sebagai tingkat penggunaan hutang sebagai sumber biaya perusahaan. Financial leverage yang digunakan adalah Debt to Equity Ratio (DER) atau sering disebut rasio kebijakan hutang. Rasio ini biasa digunakan untuk mengukur financial leverage perusahaan (Lukman Syamsudin, 2007). Angka DER yang tinggi akan mempengaruhi penilaian investor sehingga dapat menyebab-kan harga saham menurun (Putu Dina A., 2013).

\section{Kebijakan Dividen}

Dividen adalah nilai pendapatan bersih perusahaan setelah pajak dikurangi dengan laba ditahan. Kebijakan dividen yang optimal adalah menciptakan seimbang dividen saat ini dan pertumbuhan dimasa mendatang (Weston dan Brigham, 2005). Penghentian dan 
pengurangan dividen dianggap sinyal negatif oleh investor pada perkembangan perusahaan di masa datang (Michael C. Jensen,1986). Membagi laba sebagai dividen berarti akan mengurangi sumber dana intern. Sebaliknya perusahaan tidak membagikan labanya sebagai dividen bisa memperbesar sumber dana intern untuk peningkatan kemampuan perusahaan (Candra Pami H., 2014).

\section{Nilai Perusahaan}

Nilai perusahaan didefinisikan sebagai nilai pasar atau Price Book Value (PBV). PBV mengukur nilai yang diberikan pasar keuangan kepada manajemen dan organisasi perusahaan sebagai sebuah perusahaan yang terus tumbuh (Brigham dan Houston, 2011:430). PBV merupakan rasio antara harga saham terhadap nilai bukunya. PBV mengambarkan seberapa besar pasar menghargai nilai buku saham suatu perusahaan. Semakin tinggi rasio ini berarti pasar percaya akan prospek perusahaan (Wardani, 2011).

\section{Harga Saham}

Harga Saham didefinisikan sebagai harga pasar. harga pasar adalah harga penutupan (closing price). Harga pasar ini menyatakan naik turunnya suatu saham,(Abdul Halim, 2005). Analisis yang paling sesuai dengan harga saham adalah analisis fundamental yaitu untuk perhitungan risiko dan keuntungan yang bisa diterima berupa dividen atau capital gain (Danika Reka Artha, 2014).

\section{Kerangka Pikir Penelitian}

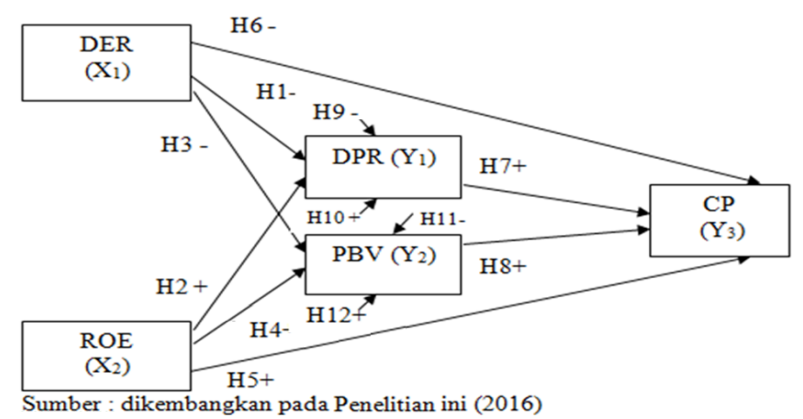

Ringkasan Hipotesis

\begin{tabular}{|l|l|}
\hline Variabel & \multicolumn{1}{|c|}{ Hipotesis } \\
\hline H1 & DER berpengaruh negatif terhadap DPR. \\
\hline H2 & ROE berpengaruh positif terhadap DPR. \\
\hline H3 & DER berpengaruh negatif terhadap PBV. \\
\hline H4 & ROE berpengaruh positif terhadap PBV. \\
\hline H5 & ROE berpengaruh positif terhadap CP. \\
\hline H6 & DER berpengaruh negatif terhadap CP. \\
\hline H7 & DPR berpengaruh positif terhadap CP. \\
\hline H8 & PBV berpengaruh positif terhadap CP. \\
\hline H9 & DPR memediasi pengaruh DER terhadap CP. \\
\hline H10 & DPR memediasi pengaruh ROE terhadap CP. \\
\hline H11 & PBV memediasi pengaruh DER terhadap CP. \\
\hline H12 & PBV memediasi pengaruh ROE terhadap CP. \\
\hline Sumber : dikembangkan pada penelitian ini (2016)
\end{tabular}

Metode Penelitian

\section{Sumber Data, Populasi dan Sampel}

Sumber data adalah data sekunder dari internet website IDX (http://www.idx.co.id). Populasinya adalah perusahaan LQ45 non lembaga keuangan yang tercatat di Bursa Efek Indonesia yang membagikan dividen minimal satu kali pada periode pengamatan antara 2011-2015 berjumlah 54 perusahaan. Sampel Sensus atau sampel jenuh, seluruh anggota populasi yang diamati semua, setelah disaring jumlah data amatan adalah 150 .

\section{Teknik Analisis Data}

Teknik analisis data dalam penelitian ini adalah dengan uji regresi linier, uji kelayakan model, uji hipotesis mengunakan aplikasi SPSS dan uji mediasi mengunakan Sobel Test.

\section{Model Persamaan Struktural}

$Y_{1}=a+b_{1} X_{1}+b_{2} X_{2}+e_{1}$

$Y_{2}=a+b_{3} X_{1}+b_{4} X_{2}+e_{2}$

$\mathrm{Y}_{3}=\mathrm{a}+\mathrm{b}_{5} \mathrm{X}_{2}+\mathrm{b}_{6} \mathrm{X}_{1}+\mathrm{b}_{7} \mathrm{Y}_{1}+\mathrm{b}_{8} \mathrm{Y}_{2}+\mathrm{e}_{3}$

\section{Hasil dan Pembahasan}

\section{Hasil Uji Kelayakan Model (SPSS)}

Hasil Uji, nilai adjusted $\mathrm{R}^{2}$ model kesatu $11,1 \%$. model kedua $51,3 \%$ dan model ketiga $23,7 \%$. Terdapat variabel lain yang dapat menjelaskan DPR 88,9\%. Menjelaskan PBV 48,7\% dan menjelaskan CP 76,3\%.

\section{Hasil Uji Regresi Linier Berganda (SPSS)}

Uji Statistik $t$ Model Pertama

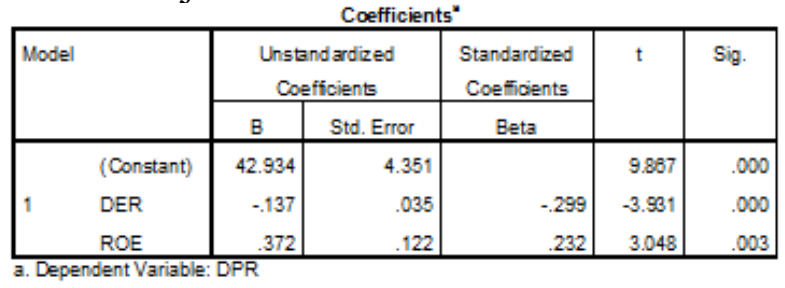

Uji Statistik $t$ Model Kedua 


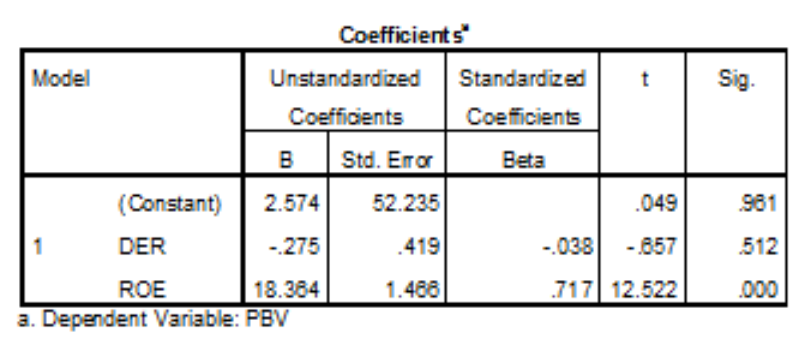

Uji Statistik $t$ Model Ketiga

\begin{tabular}{|c|c|c|c|c|c|c|}
\hline \multirow[t]{2}{*}{ Mod } & & \multicolumn{2}{|c|}{$\begin{array}{c}\text { Unstandardized } \\
\text { Coefficients }\end{array}$} & \multirow{2}{*}{$\begin{array}{c}\text { Standardized } \\
\text { Coefficients }\end{array}$} & \multirow[t]{2}{*}{$\mathrm{t}$} & \multirow[t]{2}{*}{ Sig. } \\
\hline & & $\mathrm{B}$ & Std. Error & & & \\
\hline \multirow{5}{*}{1} & (Constant) & -2051.980 & 3438.385 & & -.597 & .551 \\
\hline & ROE & 127.832 & 105.887 & .125 & 1.207 & .229 \\
\hline & DER & -11.889 & 22.138 & -.041 & -.537 & .592 \\
\hline & DPR & 115.511 & 51.813 & .181 & 2.229 & .027 \\
\hline & PBV & 12.238 & 4.316 & .305 & 2.835 & .005 \\
\hline
\end{tabular}

\section{Persamaan Regresi}

$\mathrm{DPR}=42,934+-0,137$ DER $+0,372$ ROE $+0,927$

$\mathrm{PBV}=2,574+-0,275$ DER $+18,364$

$\mathrm{ROE}+0,698$

$\mathrm{CP}=-2051,980+127,832 \mathrm{ROE}+-11,889 \mathrm{DER}$

$$
+115,511 \mathrm{DPR}+12,238 \mathrm{PBV}+0,873
$$

Dimana:

$\mathrm{e}_{1}=\sqrt{1-0,141}=0,927$

$\mathrm{e}_{2}=\sqrt{1-0,513}=0,698$

$\mathrm{e}_{3}=\sqrt{1-0,237}=0,873$

\section{Analisis Hasil Uji Hipotesis}

1).Pengaruh DER terhadap DPR hasil t hitung $-3,931$ dan sig. $0,000<0,05 . \mathrm{H}_{1}$ diterima.

2).Pengaruh ROE terhadap DPR hasil t hitung 3,048 dan sig. $0,003<0,05$. $\mathrm{H}_{2}$ diterima.

3).Pengaruh DER terhadap PBV hasil $t$ hitung $-0,657$ dan sig. 0,512 >0,05. $\mathrm{H}_{3}$ ditolak.

4).Pengaruh ROE terhadap PBV hasil thitung 12,522 dan sig. $0,000<0,05 . \mathrm{H}_{4}$ diterima.

5).Pengaruh ROE terhadap $\mathrm{CP}$ hasil $\mathrm{t}$ hitung 1,207 dan sig.0,229 > 0,05. $\mathrm{H}_{5}$ ditolak.

6).Pengaruh DER terhadap $\mathrm{CP}$ hasil t hitung $-0,537$ dan sig. $0,592>0,05 . \mathrm{H}_{6}$ ditolak

7).Pengaruh DPR terhadap CP hasil t hitung 2,229 dan sig. $0,027<0,05 . \mathrm{H}_{7}$ diterima.

8).Pengaruh PBV terhadap CP hasil $\mathrm{t}$ hitung 2,835 dan sig. $0,005<0,05 . \mathrm{H}_{8}$ diterima.

\section{Hasil Uji Mediasi (Sobel Test)}

9). Uji mediasi,hasil DPR memediasi pengaruh DER terhadap $\mathrm{CP}$ dengan $\mathrm{t}$ hitung $-1,9372>\mathrm{t}$ table -1,65543. Hipotesis $\mathrm{H}_{9}$ diterima.

10). Didapat hasil DPR memediasi pengaruh ROE terhadap CP dengan $\mathrm{t}$ hitung $1,7996>\mathrm{t}$ table 1,65543. Hipotesis $\mathrm{H}_{10}$ diterima.
11). Didapat hasil PBV memediasi pens $\mathrm{H}_{11}$ ditolak.

12). Didapat hasil PBV memediasi pengaruh ROE terhadap CP dengan $\mathrm{t}$ hitung 2,7655 $>\mathrm{t}$ table 1,65543. Hipotesis $\mathrm{H}_{12}$ diterima.

\section{Pembahasan}

1). $\mathrm{H}_{1}$ diterima dengan arah negatif memiliki arti semakin kecil DER maka pengaruh terhadap DPR semakin besar. Jika jumlah nilai DER naik maka menyebabkan penurunan nilai DPR. Hal tersebut sejalan dengan penelitian Nuriyatul (2015) dan Abdul Kadir (2010).

2). $\mathrm{H}_{2}$ diterima dengan arah positif memiliki arti Semakin besar nilai ROE maka DPR akan meningkat. ROE mencerminkan laba usaha manajemen yang bertindak sebagai Agen dan merupakan sinyal positif pemegang saham memperoleh dividen. Sejalan dengan penelitian Ismawan Yudi (2014) dan Fahjriyah (2011).

3). $\mathrm{H}_{3}$ ditolak dengan arah negatif memiliki arti semakin tinggi atau rendah DER tidak mampu mempengaruhi PBV dan tidak terlalu di- perhatikan investor. Sejalan dengan penelitian Bhekti Fitri (2013) dan Candra Pami (2014).

4). $\mathrm{H}_{4}$ diterima dengan arah positif memiliki arti semakin besar ROE akan meningkatkan PBV. Nilai ROE tinggi mengindikasi prospek perusahaan baik sehingga memicu investor meningkat permintaan saham, berakibat PBV meningkat. Hal ini sejalan dengan penelitian Candra Pami (2014) dan Putri Dwi (2014).

5). $\mathrm{H}_{5}$ ditolak dengan arah positif memiliki arti ROE kurang cocok dijadikan sebagai acuan membuat keputusan investasi sebab pengaruh- nya tidak signifikan terhadap CP. Sejalan dengan penelitian Raghilia Amanah (2014).

6). $\mathrm{H}_{6}$ ditolak dengan arah negatif memiliki arti semakin tinggi menggunakan pendanaan dari hutang maka semakin rendah harga saham dimata investor dan sebaliknya. sejalan dengan penelitian Putu D(2013) dan Danika R.(2014).

7). $\mathrm{H}_{7}$ diterima dengan arah positif memiliki arti semakin tinggi DPR, maka semakin tinggi pula CP dan sebaliknya. sejalan dengan penelitian Rescyana Putri (2012).

8). $\mathrm{H}_{8}$ diterima dengan arah positif memiliki arti semakin besar BPV maka CP yang didapatkan semakin tinggi yang memberikan 
harapan para investor keuntungan yang lebih besar. Hal tersebut sejalan dengan penelitian Danika Reka (2014) dan Putu Dina (2013).

9). $\mathrm{H}_{9}$ diterima dengan arah negatif dengan hasil nilai koefisien mediasi yang signifikan berarti, bahwa ada pengaruh mediasi antara DER terhadap CP melalui DPR.

10). $\mathrm{H}_{10}$ diterima dengan arah positif dengan hasil nilai koefisien mediasi signifikan berarti, bahwa ada pengaruh mediasi antara ROE terhadap CP melalui DPR.

11). $\mathrm{H}_{11}$ ditolak dengan arah negatif dengan hasil nilai koefisien mediasi tidak signifikan, berarti bahwa tidak ada pengaruh mediasi antara DER terhadap CP melalui BPV.

12). $\mathrm{H}_{12}$ diterima dengan arah positif dengan hasil nilai koefisien mediasi signifikan, berarti bahwa ada pengaruh mediasi antara ROE terhadap CP melalui BPV.

\section{Kesimpulan}

1).Pengaruh negatif dan signifikan DER terhadap DPR dengan $\mathrm{t}$ hitung $-3,931>\mathrm{t}$ table $-1,65543$ dan nilai sig. $0,000<0,05$. Disimpulkan Hipotesa $\mathrm{H}_{1}$ diterima.

2).Pengaruh positif dan signifikan $\mathrm{ROE}$ terhadap DPR dengan thitung 3,048 $>\mathrm{t}$ tabel 1,65543 dan nilai sign. $0,003<0,05$. Disimpulkan Hipotesa $\mathrm{H}_{2}$ diterima.

3).Pengaruh negatif dan tidak signifikan DER terhadap PBV dengan $\mathrm{t}$ hitung $-0,657<\mathrm{t}$ tabel $-1,65543$ dan nilai sign. $0,512>0,05$. Disimpulkan Hipotesa $\mathrm{H}_{3}$ ditolak.

4).Pengaruh positif dan signifikan ROE terhadap PBV dengan $\mathrm{t}$ hitung 12,522 $>\mathrm{t}$ table 1,65543 dan nilai sign. $0,000<0,05$. Disimpulkan Hipotesa $\mathrm{H}_{4}$ diterima.

5).Pengaruh positif tidak signifikan ROE terhadap $\mathrm{CP}$ dengan $\mathrm{t}$ hitung $1,207<\mathrm{t}$ tabel 1,65543 dan nilai sign. $0,229>0,05$. Disimpulkan Hipotesa $\mathrm{H}_{5}$ ditolak.

6).Pengaruh negatif tidak signifikan DER terhadap $\mathrm{CP}$ dengan $\mathrm{t}$ hitung $-0,537<\mathrm{t}$ tabel $-1,65543$ dan nilai sign. 0,592 >0,05. Disimpulkan Hipotesa $\mathrm{H}_{6}$ ditolak.

7).Pengaruh positif dan signifikan DPR terhadap $\mathrm{CP}$ dengan $\mathrm{t}$ hitung 2,229 $>\mathrm{t}$ tabel 1,65543 dan nilai sign. $0,027<0,05$. Disimpulkan Hipotesa $\mathrm{H}_{7}$ diterima.

8).Pengaruh positif dan signifikan PBV terhadap $\mathrm{CP}$ dengan $\mathrm{t}$ hitung 2,835 $>\mathrm{t}$ tabel 1,65543 dan nilai sign.0,005 $<0,05$. Disimpulkan Hipotesa $\mathrm{H}_{8}$ diterima.
9).Pengaruh negatif signifikan DER terhadap CP dengan DPR sebagai variabel mediasi. Nilai t hitung $-1,891>\mathrm{t}$ tabel $-1,65543$. Disimpulkan Hipotesa $\mathrm{H}_{9}$ diterima

10).Pengaruh positif signifikan ROE terhadap CP dengan DPR sebagai variabel mediasi. Nilai t hitung 1,7397 > t tabel 1,65543. Disimpulkan Hipotesa $\mathrm{H}_{10}$ diterima.

11).Pengaruh tidak signifikan DER terhadap $\mathrm{CP}$ dengan PBV sebagai variabel mediasi. Nilai t hitung $-0,6047<\mathrm{t}$ tabel $-1,65543$. Disimpulkan Hipotesa $\mathrm{H}_{11}$ ditolak.

12).Pengaruh signifikan ROE terhadap $C P$ dengan PBV sebagai mediasi. Nilai t hitung 2,7571 $>\mathrm{t}$ tabel 1,65543. Disimpulkan Hipotesa $\mathrm{H}_{12}$ diterima.

\section{Saran Penelitian Mendatang}

1).Ditambahkan populasi perusahaan sebagai sampel tidak terbatas pada emiten LQ45 saja.

2).Ditambahkan variabel independen diluar model penelitian untuk melengkapi faktorfaktor yang mempengaruhi DPR dan CP.

3).Mengunakan data rata-rata harga saham seminggu setelah publikasi laporan keuangan untuk penelitian yang akan datang.

\section{Referensi}

[1] Abdul Kadir,"Analisis Faktor-Faktor Yang Mempengaruhi Kebijakan Dividen Pada Perusahaan Credit Agencies Go Public di (BEI)“. Jurnal Mnj Akt Vol.11,No.1(2010).

[2] Abied Luthfi,"Pengaruh Earning per Share, Price Earning Ratio, Return on Asset, Debt to Equity Ratio dan Market Value Added Terhadap Harga Saham Dalam Kelompok Jakarta Islamic Index". Management Analysis Journal, MAJ 2 (2),ISSN 2252-6552, (2013).

[3] Bhekti Fitri P.," Pengaruh Ukuran Perusahaan, Leverage, Price Earning Ratio dan Profitabilitas Terhadap Nilai perusahaan ", Jurnal Ilmu Manajemen, Vol.1, No.1,(2013).

[4] Candra Pami H,"Pengaruh Profitabilitas, Kebijakan Dividen, Kebijakan hutang, Keputusan Investasi, dan Kepemilikan Inside Terhadap Nilai perusahaan", Jurnal Ilmu \& Riset Akuntansi Vol.3 No.4, (2014).

[5] Christine Dwi, "Analisis Perbandingan Pengaruh Likuiditas, Solvabilitas, dan 
Profitabilitas Terhadap Harga Saham pada Perusahaan LQ 45 period 2006-2009", Jurnal Akuntansi Vol.4 No.2 :165-174, (2012).

[6] Daniel,"Pengaruh Faktor Internal Terhadap Harga Saham Pada Perusahaan LQ45 Yang Terdaftar di BEI', Jurnal EMBA ISSN 2303-11, Vol.3 No.3, Hal.863-876, ( 2015).

[7] Danika Reka A.,"Analisis Fundamental, Teknikal dan Makro Ekonomi Harga Saham Sektor Pertanian", Jurnal Mnj Wirausaha, 175-184 ISSN 1411-1438,(2014).

[8] Desy Arista, "Analisis Faktor - Faktor Yang Memepengaruhi Return Saham, (Perusahaan Manufaktur tahun 2005-2009)". Jurnal Ilmu Manajemen dan Akuntansi Terapan,Vol 3, No.1,(2012).

[9] Dewi Yunitasari, " Pengaruh Keputusan Investasi,Pendanaan, Kebijakan Dividen, dan Tingkat Suku bunga Terhadap Nilai perusahaan", Jurnal Ilmu \& Riset Akuntansi Vol.3 No.4 (2014).

[10] Fajriyah," Analisis Pengaruh ROE, DER, Management Owner, Free Cash Flow, dan Size Terhadap DPR pada Perusahaan Manufaktur Di BEI Periode 2006-2009”. (EJournal Undip), (2011).

[11] Fillya Arum,"Analisis fakor fundamental terhadap harga saham". Accounting Analysis Journal AAJ Vol.1 No.1, (2012).

[12] Ismawan Yudi P.," Pengaruh Leverage, Likuiditas, Profitabilitas dan Ukuran Perusahaan Terhadap Kebijakan Dividen (Perusahaan Perbankan di BEI Tahun 20102013 )",Jurnal JAB Vol.15 No.1, (2014).

[13] Mursidah N., "Analisis Pengaruh Earning Per Share, Debt to Equity Ratio dan Return on Equity Terhadap Harga Saham PT. Unilever Indonesia Tbk.". Jurnal Manajemen Akuntansi Vol12,No.1 (2011).

[14] Putri Dwi M,"Pengaruh Kebijakan Utang dan Profitabilitas Terhadap Nilai perusahaan; Kebijakan Dividen sebagai Variabel Pemoderasi periode 2008-2012", Jurnal Ilmu \& Riset Akt. Vol.3 No.2, (2014).

[15] Putu Dina A,"Pengaruh EPS, DER, dan PBV Terhadap Harga Saham (Food and Beverage di BEI periode 2009-2011)", EJurnal Akuntansi Universitas Udayana 4.1: 215229, ISSN: 2302-8556,(2013).

[16] Raghilia Amanah,"Pengaruh Rasio Likuiditas dan Rasio Profitabilitas Terhadap
Harga Saham ( Perusahaan LQ45 Periode 2008-2012 )”. (JAB) Vol.12 No.1, (2014).

[17] Rescyana Putri H.,"Pengaruh Dividen per Share, Return on Equity dan Net Profit Margin Terhadap Harga Saham Perusahaan Manufacturing di BEI Periode 2006 2010",Jurnal Nominal / Vol. I, No. I, (2012).

[18] Wardani, D. K. "Pengaruh Struktur Kepemilikan Terhadap Nilai Perusahaan Dengan Kinerja Keuangan dan Kebijakan hutang sebagai Variabel Intervening". Jurnal Siasat Bisnis.15 Vol (1): 27-36, (2011).

[19] Wendy Cahyono, "Pengaruh Rasio Probabilitas, DER, PBV dan PER Terhadap Harga Saham Perusahaan Jakarta Islamic Index (JII)". Proceeding SemNas Hal 264275. ISBN: 978-979-636-147-2 (2013).

[20] Zumrotun Nafi'ah,"Analis Faktor-Faktor yang mempengaruhi Kebijakan Dividend an Dampaknya Terhadap Nilai Perusahaan pada Perusahaan Manufactur yang tercatat di BEI Tahun 2008-2010", Jurnal STIE Semarang, Vol.5,No.3,Edisi Okt(2013) (ISSN:2252-7826).

Referensi buku:

[21] Abdul Halim. “Analisis Investasi”. Edisi Kedua. Jakarta : Salemba Empat, (2005).

[22] Brigham, E,F \& Weston, J,F."DasarDasar Manajemen Keuangan, Edisi-9”, Jilid2, Penerbit Erlangga, Jakarta, (2005).

[23] Brigham, Eugene F. dan Joel F. Houston." Dasar-dasar Manajemen Keuangan ", Edisi 11, Penerjemah Ali Akbar Yulianto, Salemba Empat, Jakarta, 2011.

[24] Keown, A.J, "Dasar-dasar Manajemen Keuangan”, BPE, Jakarta, (1999).

[25] Lukman Syamsudin"Manajemen keuangan perusahaan". Jakarta: Raja Grafindo Persada, (2007).

[26] Michael C. Jensen \& William H. Meckling," Theory of the Firm: Managerial Behavior, Agency Costs and Ownership Structure", Journal of Financial Economics, October, 1976, V. 3, No. 4, pp. 305-360.

[27] Niswonger, Warren, Reeve, Fess. "Prinsip-Prinsip Akuntansi", Edisi 19. Penerbit Erlanga. Jakarta,(2004).

Referensi bab dalam buku:

[28] Information on website IDX; http://www.idx.co.id website kompas; http://www.kompas.com 